\title{
Insertion Torque of Mini Dental Implants and their Failure Risk after Immediate Loading
}

\author{
Torque de Inserción de Mini Implantes Dentales y su Riesgo \\ de Fracaso cuando son Cargados Inmediatamente
}

Jofre, J.; Conrady, Y."* \& Lagos-Álvarez, B."**

JOFRE, J.; CONRADY, Y. \& LAGOS-ÁLVAREZ, B. Insertion torque of mini dental implants and their failure risk after immediate loading. Int. J. Odontostomat., 8(3):351-358, 2014.

\begin{abstract}
A minimum insertion torque has been suggested for immediate function of regular diameter implants. Even when there is a growing tendency to use Mini Dental Implants (MDIs) for immediate function of dentures, there is no clinical data concerning MDIs insertion torque, nor its influence on implant failure. The aim of this prospective study was to assess the insertion torque of immediate loaded MDIs in edentulous patients and its association with risk failure. Ninety MDIs were placed in the anterior mandible of 45 edentulous patients, two per patient. The insertion torque was recorded with an electronic device and failures were documented during two years follow-up. All implants were immediately loaded with overdentures, using ball (44/90) or bar (46/90) attachments. A Kaplan-Meier survival probability estimator and a fitted multiple Cox regression model were performed to establish the influence of insertion torque and other clinical parameters on implant risk failure. The average insertion torque of 90 MDls was $12.5 \pm 7.8 \mathrm{Ncm}$. A cumulative survival rate of $94.2 \%(5 / 90)$ was found by means of the Kaplan-Meier estimation. The Cox proportional-hazards regression model showed no association between insertion torque and MDIs failure. MDIs have much lower insertion torque than average conventional implants. The insertion torque of MDIs immediately loaded with mandibular dentures, seems not to be a risk factor associated to failure, at two years follow-up.
\end{abstract}

KEY WORDS: mini dental implant, insertion torque, denture, overlay, mini implant failure, jaw, edentulous.

\section{INTRODUCTION}

Mini dental implants (MDIs) have been reported as an alternative treatment for patients with totally edentulous mandibles (Christensen, 2006; Bulard \& Vance, 2005; Shatkin et al., 2007; Siddiqui et al., 2006). Advantages of this procedure include implant placement in horizontally narrow sites, minimally invasive surgery and the possibility to load the implants immediately (Cho et al., 2007; Velasco Ortega et al., 2004; LaBarre et al., 2008; Preoteasa et al. 2010). MDIs are one-piece implant designed to be loaded immediately after insertion (Griffitts et al., 2005).

Implant primary stability has been considered to be one of the key factors for immediate loading
(Esposito et al., 2007) and several studies have validated the insertion torque for conventional implants as an objective measure of primary stability (Albrektsson et al., 1981; Cehreli et al., 2009). A minimum insertion torque of 32 to $35 \mathrm{Ncm}$ has been suggested as the requirement for immediate implant function or loading (Uribe et al., 2005; Horiuchi et al., 2000; Misch et al., 2004); however, there is no data in the literature regarding the minimal insertion torque required for MDIs, nor the influence of primary stability on the prognosis of this treatment.

The surface area of an MDI is about $1 / 4$ of a standard diameter implant (Flanagan \& Mascolo,

Director, Center for Advanced Prosthodontics and Implant Dentistry (CRAI), University of Concepción, Concepción, Chile.

* Researcher, Center for Advanced Prosthodontics and Implant Dentistry (CRAI), University of Concepción, Concepción, Chile.

*** Statistician, Department of Statistics, Faculty of Physical and Mathematical Sciences, University of Concepción, Concepción, Chile. This research was supported by a grant from the National Commission for Scientific and Technological Research of Chile (CONICYT), through the Fund for the Promotion of Scientific and Technological Development (FONDEF Project Di1109) and DIUC 213.014.022-1.0 University of Concepcion, Chile. 
2010), resulting in less mechanical anchor. This was evaluated in recent in vitro tests in which torque values for MDIs were far below the minimal standards required for the immediate loading of conventional implants (Dilek et al., 2008).

The purpose of this study was to assess the insertion torque values of MDIs and their associations with implant failure after immediate loading.

\section{MATERIAL AND METHOD}

Patients and treatment. This study is a part of a twoyear, single-center, randomized clinical trial (Jofre et al., 2010a, 2010b) that evaluated the clinical and biomechanical behavior of overdentures using two retention systems. All participants received oral and written information about the trial prior to signing a written informed consent to participate. The study protocol was approved by the Ethics Committee of the University of Concepcion and the Chilean "National Commission on Scientific and Technological Research".

Totally edentulous patients suffering persistent retention problems with their overdentures were recruited at a public health center in Concepcion, Chile. The trial included male and female edentulous patients between 45 and 90 years old with no medical condition contraindicating implant surgery and no TMD (Temporomandibular Disorder). Patients with an uncontrolled systemic disease (e.g. hypertension, diabetes), those with diagnosis of severe osteoporosis and/or taking biphosphonates, patients with mental disorders, and those receiving radiotherapy in the 18 months before the trial were excluded.

Prosthetic procedure. All dentures were made with anatomical teeth (Marche Ltda., Santiago, Chile). A prosthodontist re-established the vertical dimension of all participants. Furthermore, the extension and prosthetic fit was improved at the maxillary and mandibular prostheses relining with a low-exothermic acrylic resin (Tokuyama, J. Morita Corp., Tokyo, Japan. Dynamic occlusion was checked by using articulating paper to confirm a balanced bilateral occlusal scheme.

Surgical phase. In all patients panoramic X-rays (Auto III ECM Asahi, Roegten ind CO: Ltda. Japan) were taken and software for cephalometrics (Radiocef 2.0 Radiomemory, Belo Horizonte, MG, Brazil) were used to evaluate the bone height available in the mandible. Mini implants of $15 \mathrm{~mm}$ length were necessary for the entire sample.

Each patient received a prophylactic antibiotic (amoxicillin) one hour prior to $(2 \mathrm{~g})$ and six hours after surgery $(500 \mathrm{mg})$, plus a non-steroidal antiinflammatory lbuprofen $600 \mathrm{mg}$ one hour prior to and $400 \mathrm{mg}$ orally every 8 hours for 2 days after surgery (Friberg, 1999; Naert et al., 1998). A total of 90 MDIs $(1.8 \times 15 \mathrm{~mm}$ ) (Sendax® MDI, IMTEC, Ardmore, OK USA) sandblasted and acid-etched surfaces were inserted in the anterior mandibular zone of selected participants (two per patient) using a drilling device that allowed measuring cutting resistance (Osseocare $\AA$, DEC 600, Nobel Biocare AB, Göteborg, Sweden).

Following instructions of the manufacturer, only one drill of $1.1 \mathrm{~mm}$ diameter was used for routine bone preparation. The perforation depth was always $7 \mathrm{~mm}$, near half of the implant length. Implants of $1.8 \mathrm{~mm}$ diameter were then totally inserted using their selftapping properties. To control an accurate insertion of the implant into the jaw bone by performing a flapless procedure, a standard surgical guide was used (US patent $\left.\mathrm{N}^{\circ} 7682151 \mathrm{~B} 2\right)$. The standard guide also allowed the use of a prefabricated bar, which was applied in twenty-three patients (46 of 90 implants). The rest of the patients were treated using ball attachment (44 out of 90 implants).

After insertion, all implants were immediately loaded fitting the patient's denture and fixing a clip or o'ring attachment by using acrylic resin (Alike; GC America, Alsip, IL).

The dynamic occlusion was evaluated by using articulating paper and a balanced bilateral occlusal scheme with stable dental contacts was confirmed. The patients were instructed in appropriate oral hygiene techniques and post-operatory care.

Assessment. The primary outcome was to assess the MDIs insertion torque values and their associations with risk of implant failure.

The secondary outcome was the association between the risk of implant failure with other clinical factors (e.g keratinized tissue, index plaque, attachment system and bone loss).

The following clinical measures were recorded: 
Insertion torque. The average insertion torque from three zones (crestal, middle, and apical) was obtained automatically by means of an electronic device (Osseocare $\AA$, DEC 600, Nobel Biocare AB, Göteborg, Sweden) (Friberg).

For the statistical analysis, only the apical zone was used, as final insertion torque.

Implant failure. The criterion of Naert and Chiapasco (Naert et al.; Chiapasco \& Gatti, 2003) was used to assess MDI failures. This criterion is based on the classical Albrektsson and Zarb criterion (Albrektsson et al., 1986) but adapted for implant overdentures.

Implant failure was defined as removal of the implant due to any of the following signs and symptoms during the evaluation:

1) The implant showed signs or symptoms, such as pain or infection.

2) Peri-implant radiolucency evaluated on panoramic radiographs.

3) The individual implant showed signs of mobility at clinical assessment, which normally led to implant removal.

\section{Clinical Parameters}

Bone loss at 2 years follow-up. Standardized retroalveolar radiographs of each mini-implant were taken using a long-cone technique with a device that allowed a reproducible unidirectional focus (Jofre et al., 2010a, 2010b).

Keratinized tissue. The width of the keratinized gingiva was measured by means of a periodontal probe, painting the gingiva and alveolar mucosa with Schiller iodine solution (5\% iodine and $10 \%$ potassium iodide). The keratinized tissue remains unstained because this tissue is glycogen-free (Maurer et al., 2000).

Plaque index. The bacterial plaque was evaluated according to the modified Plaque Index of Mombelli (Mombelli et al., 1987). Tartar was removed using a plastic curette when necessary (Rutar et al., 2001). The highest value recorded from four sites around each implant (mesiobuccal, mesiolingual, distobuccal, and distolingual) was considered for the statistical analysis. Plaque Index ( $\mathrm{Pl}$ ) was dichotomized considering from 0 to 2 as "low level" and 3 as "high level".
Prosthetic attachment system. Two attachment systems were used in this study: 1) ball system was used in 22 patients, 44 single-standing ball- type MDIs 2) bar system was used in 43 patients, 46 squareheaded MDIs splinted with a $2 \mathrm{~mm}$ diameter prefabricated round bar.

Statistical analysis. Data was analyzed using SPSS version 15.0 (SPSS Inc. Chicago, IL, USA). All mini implants were pooled for statistical analysis. Descriptive statistics (mean and standard deviation) of the insertion torque were calculated at the level of the implant (insertion torque value was calculated for each mini implant).

Using R Statistical Software Version: 2.15.0, a Kaplan-Meier estimator was used to obtain the survival rate of MDIs survival at two-year period. The Cox proportional hazards regression model was performed to establish the influence of insertion torque and other clinical parameters of implant risk failure. $P$ values less than 0.05 were considered statistically significant.

\section{RESULTS}

Demographic and morbidities data of the sample are shown in Table I. The average insertion torque of 90 MDls was $12.5 \pm 7.8 \mathrm{~N} / \mathrm{cm}$ (Min: 3.0 - Max: 23.7) and is shown in Figure 1.

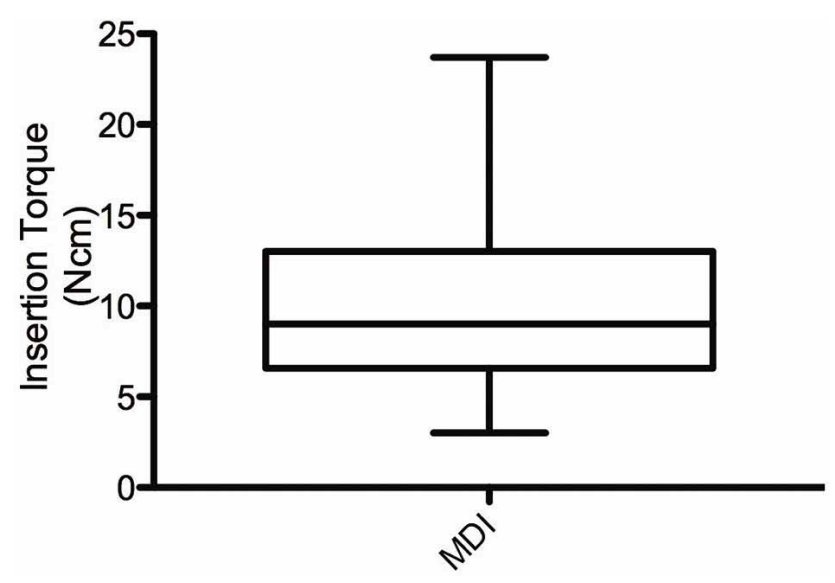

Fig. 1. Insertion Torque distribution in MDIs samples ( $n=90)$.

Insertion torque distribution of failing MDIs compared with the successful ones, are shown in Figure 2 . 
After two years of follow-up, five MDIs failed in 4 patients (5/90 MDIs). Kaplan and Meier analysis revealed a survival rate of $94.2 \%$ (Fig. 3).

The recorded clinical parameters of the failed implants are described in Table II. The multivariate Cox regression model was fitted for analysis of potential association between the studied parameters and the probability of implant failure. Table III, shows the $95 \%$ confidence interval for the hazard ratio and $p$-values.

The results showed no association between studied clinical variables, including insertion torque and risk of implant failure.

Table I. Baseline patient characteristics.

\begin{tabular}{|c|c|c|c|c|}
\hline & & Group-ball & Group-bar & $\begin{array}{c}\text { Difference between } \\
\text { groups }\end{array}$ \\
\hline $\operatorname{Sex}(F / M)$ & & $13 / 9$ & $14 / 9$ & $>0.999^{*}$ \\
\hline Age (years) & & $69 \pm 8.7$ & $73 \pm 9.6$ & $0.106^{*}$ \\
\hline \multirow[t]{3}{*}{ Morbid conditions } & Diabetes & $2 / 22$ & $3 / 23$ & $>0.999^{*}$ \\
\hline & Osteoporosis & $1 / 22$ & $0 / 23$ & $0.489^{*}$ \\
\hline & Smoking & $1 / 22$ & $1 / 23$ & $>0.999^{*}$ \\
\hline
\end{tabular}

Table II. Clinical parameters at the time of MDI failure.

\begin{tabular}{ccccccc}
\hline Implant & $\begin{array}{c}\text { Failure Time } \\
\text { (Month) }\end{array}$ & $\begin{array}{c}\text { Attachment } \\
\text { System }\end{array}$ & $\begin{array}{c}\text { Keratinized } \\
\text { Tissue }(\mathbf{m m})\end{array}$ & $\begin{array}{c}\text { Plaque } \\
\text { Index }\end{array}$ & $\begin{array}{c}\text { Bone Loss } \\
(\mathbf{m m})\end{array}$ & $\begin{array}{c}\text { Insertion } \\
\text { Torque (Ncm) }\end{array}$ \\
\hline 1 & 6 & Ball & 5 & 2 & 1.13 & 7 \\
2 & 6.5 & Ball & 4.5 & 2 & 1.13 & 13 \\
3 & 10 & Ball & 2 & 2 & 2 & 10.3 \\
4 & 10 & Bar & 4 & 3 & 1.75 & 13 \\
5 & 12 & Ball & 4 & 0 & 1.38 & 10.3 \\
\hline
\end{tabular}

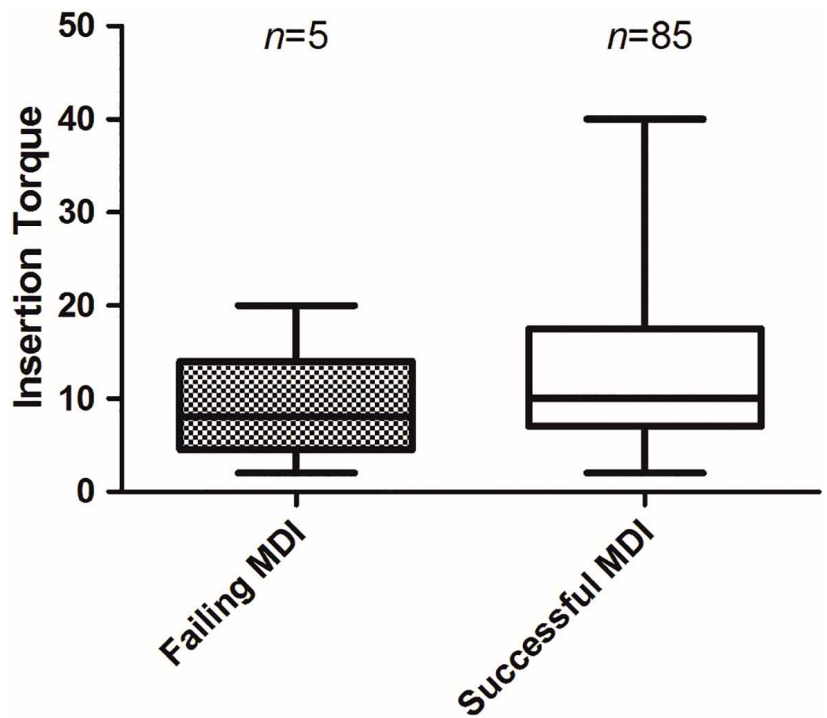

Fig. 2. Boxplot showing the insertion torque value distribution of failing and successful mini implants (MDIs).

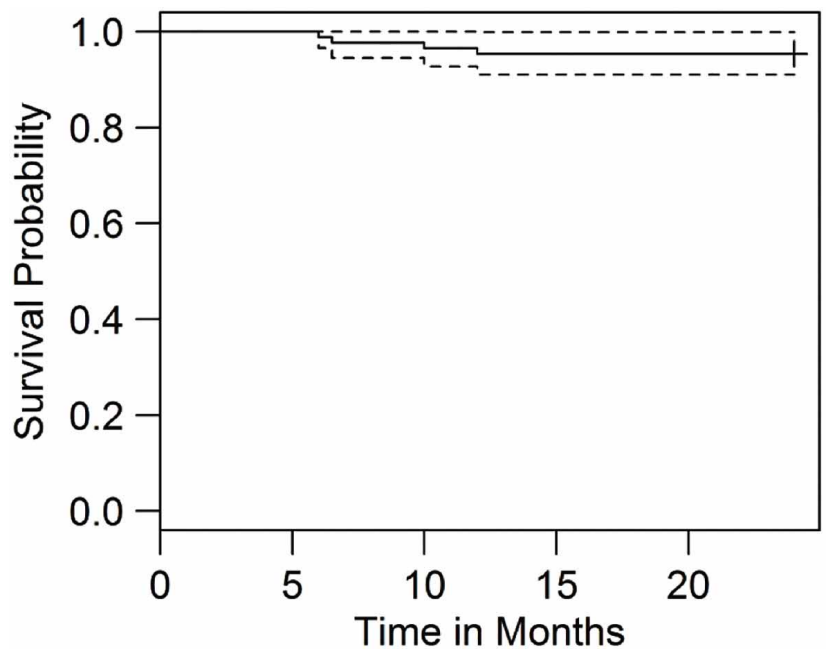

Fig. 3. Kaplan-Meier survival plot for MDIs failures at two years follow-up (95\% confidence interval). 
Table III. Cox regression analysis of the different variables and the probability of implant failure $(n=86)$.

\begin{tabular}{lccc}
\hline Clinical Variables & Hazard ratio & $\begin{array}{c}\text { Cl (95\%) } \\
\text { Lower-Upper }\end{array}$ & P-Value \\
\hline Insertion torque & 1.11 & $0.90-1.37$ & 0.34 \\
Attachment system & 13.11 & $0.50-346.65$ & 0.12 \\
Bone loss & 1.00 & $0.48-2.11$ & 0.98 \\
Keratinized Tissue & 0.95 & $0.60-1.49$ & 0.82 \\
Plaque Index & 7.16 & $0.23-226.19$ & 0.26 \\
\hline
\end{tabular}

\section{DISCUSSION}

Studies of up to 3 years of follow-up have shown that MDIs retaining overdentures might be a successful treatment option for overdentures (Jofre et al., 2010a, 2010b; Scepanovic et al., 2012; Elsyad et al., 2011; Morneburg \& Pröschel, 2008; Cho et al.).

The MDIs were designed for immediate loading (Zahran et al., 2013;,Sendax 1996; Nazarian 2005) despite possible disadvantages due to their narrow diameter $(1.8 \mathrm{~mm})$, which results in less implant-bone contact than occurs with the wider diameter implants.

Immediately after insertion, anchorage is achieved purely mechanically, arising from a combination of the bone's displacement and compression; this is defined as primary stability (Florvaag et al., 2010; Elias et al., 2012). Primary stability is determined by the bone-implant stiffness and depends on bone quality, implant geometric design, and surgical technique (Sennerby \& Meredith, 2008). In our trial, implant geometry, diameter, length and also surgical technique were standardized.

Studies have validated the insertion torque of conventional implants as an objective measure of primary stability (Cehreli et al.; Albrektsson et al., 1981) and a range of 32 to $50 \mathrm{Ncm}$ has been proposed as the minimum insertion torque necessary for immediate implant loading (Uribe et al.; Raghoebar et al., 2003; Lekholm, 2003).

An in vitro study of bovine femoral bone (Dilek et al.) found a range of insertion torque for mini implants from 5 to $35 \mathrm{Ncm}$, which is much lower than the minimum required for conventional implants. The study also reported that torque values over $35 \mathrm{Ncm}$ could lead to a fracture of the mini implant body.

In the present study, the insertion torque was measured at the crest, middle and apical of the mini implant during insertion, as described by Friberg. However, the apical insertion torque (final value obtained) was utilized for this analysis, since this value is commonly used as clinical indicator of primary stability for immediate loading.

The torque values obtained for MDIs in mandibles of edentulous patients ranged from 3 to 23.7 $\mathrm{Ncm}$, similar to the range found by Dilek et al. However, implant survival was similar to the reported data for conventional implants (Sohrabi et al., 2012; Cooper, 2012).

Even when the diameter of these implants are narrower with low resistance to the insertion, the implant length, which in this study was $15 \mathrm{~mm}$, gives a final mechanical stiffness that could provide enough stability to receive immediate loading (Dilek et al.).

For the first time, this work shows clinical data regarding insertion torque values obtained from MDIs placed in edentulous mandibles. These results suggest that for MDIs, relatively low insertion torque compared to the generally accepted norm would seem to be sufficient to immediate loading of mandibular overdentures.

The ball attachment of MDIs showed 13.1 times more probability to fail than bar system. This trend could be explained by the improvement of biomechanical and clinical behavior, when splinting MDIs, allowing a better load distribution (Jofre et al., 2010b).

Also high plaque index values showed a risk of implant failure 7.16 times higher than implant with low plaque index.

Even when these trends were found, they did not reach the conventional levels of significance. This is probably due to the lower incidence of implant failure. 
According to the results, it was concluded that MDIs have much lower insertion torque than average conventional implants. The insertion torque of MDIs, immediately loaded with mandibular dentures, seems not to be a risk factor associated to failure at two years follow-up.

\section{ACKNOWLEDGEMENTS}

The authors would like to thank Claudia Asenjo, M.S, MSc, for the manuscript preparation.

JOFRE, J.; CONRADY, Y. \& LAGOS-ÁLVAREZ, B. Torque de inserción de mini implantes dentales y su riesgo de fracaso cuando son cargados inmediatamente. Int. J. Odontostomat., 8(3):351-358, 2014.

RESUMEN: Un mínimo torque de inserción ha sido sugerido para realizar carga inmediata de implantes de diámetro regular. Aún cuando existe una tendencia creciente a utilizar Mini Implantes Dentales (MID) para la función inmediata de las prótesis totales, no hay datos clínicos relativos a los valores de torque de inserción de estos, ni tampoco de su influencia en el fracaso del implante. El objetivo de este estudio prospectivo fue evaluar el torque de inserción de mini implantes dentales con carga inmediata en pacientes desdentados y su asociación con el riesgo de fracaso. Noventa MIDs fueron colocados en la mandíbula anterior de 45 pacientes desdentados, dos por paciente. El torque de inserción fue obtenido con un dispositivo electrónico y los fracasos fueron documentadas a dos años de seguimiento. Todos los implantes fueron cargados inmediatamente con sobredentaduras, usando un sistema de retención de bola (44/90) o barra (46/90). Se utilizó el estimador de probabilidad de sobrevida de Kaplan-Meier y el modelo riesgos proporcionales de Cox ajustado para establecer la influencia de torque de inserción y otros parámetros clínicos sobre el riesgo de fracaso del implante. El promedio de torque de inserción de 90 MIDs fue 12,5 $\pm 7,8 \mathrm{Ncm}$. Los MIDs mostraron a través de la estimación de Kaplan-Meier, una tasa de supervivencia acumulada de 94,2\% (5/90). El modelo de riesgos proporcionales de Cox reveló que no existe asociación entre el valor de torque de inserción y el fracaso MIDs. MIDs tienen un valor de torque de inserción mucho más bajo que los implantes convencionales. El torque de inserción de MIDs cargados inmediatamente con prótesis mandibulares, no parece ser un factor de riesgo asociado al fracaso, a dos años de seguimiento.

PALABRAS CLAVE: mini implantes dentales, torque de inserción, sobredentadura, fracaso de mini implante, edéntulo mandibular.

\section{REFERENCES}

Albrektsson, T.; Branemark, P. I.; Hansson, H. A. \& Lindström, J. Osseointegrated titanium implants. Requirements for ensuring a long-lasting, direct bone-to-implant anchorage in man. Acta Orthop. Scand., 52(2):155-70, 1981.

Albrektsson, T.; Zarb, G.; Worthington, P. \& Eriksson, A. R. The long-term efficacy of currently used dental implants: a review and proposed criteria of success. Int. J. Oral Maxillofac. Implants, 1(1):11-25, 1986.

Bulard, R. A. \& Vance, J. B. Multi-clinic evaluation using minidental implants for long-term denture stabilization: a preliminary biometric evaluation. Compend. Contin. Educ. Dent., 26(12):892-7, 2005.

Cehreli, M. C.; Kökat, A. M.; Comert, A.; Akkocaog`lu, M.; Tekdemir, I. \& Akça, K. Implant stability and bone density: assessment of correlation in fresh cadavers using conventional and osteotome implant sockets. Clin. Oral Implants Res., 20(10):1163-9, 2009.

Chiapasco, M. \& Gatti, C. Implant-retained mandibular overdentures with immediate loading: a 3- to 8-year prospective study on 328 implants. Clin. Implant. Dent. Relat. Res., 5(1):29-38, 2003.
Cho, S. C.; Froum, S.; Tai, C. H.; Cho, Y. S.; Elian, N. \& Tarnow, D. P. Immediate loading of narrow-diameter implants with overdentures in severely atrophic mandibles. Pract. Proced. Aesthet. Dent., 19(3):16774, 2007.

Christensen, G. J. The 'mini'-implant has arrived. J. Am. Dent. Assoc., 137(3):387-90, 2006.

Cooper, L. F. Factors influencing primary dental implant stability remain unclear. J. Evid. Based Dent. Pract., 12(3 Suppl.):185-6, 2012.

Dilek, O.; Tezulas, E. \& Dincel, M. Required minimum primary stability and torque values for immediate loading of mini dental implants: an experimental study in nonviable bovine femoral bone. Oral Surg. Oral Med. Oral Pathol. Oral Radiol. Endod., 105(2):e207, 2008.

Elias, C. N.; Rocha, F. A.; Nascimento, A. L. \& Coelho, P. G. Influence of implant shape, surface morphology, surgical technique and bone quality on the primary stability of dental implants. J. Mech. Behav. Biomed. Mater., 16:169-80, 2012. 
Elsyad, M. A.; Gebreel, A. A.; Fouad, M. M. \& Elshoukouki, A. $H$. The clinical and radiographic outcome of immediately loaded mini implants supporting a mandibular overdenture. A 3-year prospective study. $J$. Oral Rehabil., 38(11):827-34, 2011.

Esposito, M.; Grusovin, M. G.; Willings, M.; Coulthard, P. \& Worthington, H. V. The effectiveness of immediate, early, and conventional loading of dental implants: a Cochrane systematic review of randomized controlled clinical trials. Int. J. Oral Maxillofac. Implants, 22(6):893-904, 2007.

Flanagan, D. \& Mascolo, A. The mini dental implant in fixed and removable prosthetics: a review. J. Oral Implantol., 37(Spec. No.):123-32, 2011.

Florvaag, B.; Kneuertz, P.; Lazar, F.; Koebke, J.; Zöller, J. E.; Braumann, B. \& Mischkowski, R. A. Biomechanical properties of orthodontic miniscrews. An in-vitro study. J. Orofac. Orthop., 71(1):53-67, 2010.

Friberg, B. On bone quality and implant stability measurements. PhD thesis. Göteborg, Göteborg University, 1999.

Griffitts, T. M.; Collins, C. P. \& Collins, P. C. Mini dental implants: an adjunct for retention, stability, and comfort for the edentulous patient. Oral Surg. Oral Med. Oral Pathol. Oral Radiol. Endod., 100(5):e81-4, 2005.

Horiuchi, K.; Uchida, H.; Yamamoto, K. \& Sugimura, M. Immediate loading of Brånemark system implants following placement in edentulous patients: a clinical report. Int. J. Oral Maxillofac. Implants, 15(6):824-30, 2000.

Jofré, J.; Hamada, T.; Nishimura, M. \& Klattenhoff, C. The effect of maximum bite force on marginal bone loss of mini-implants supporting a mandibular overdenture: a randomized controlled trial. Clin. Oral Implants Res., 21(2):243-9, 2010a.

Jofre, J.; Cendoya, P. \& Munoz, P. Effect of splinting miniimplants on marginal bone loss: a biomechanical model and clinical randomized study with mandibular overdentures. Int. J. Oral Maxillofac. Implants, 25(6):1137-44, $2010 \mathrm{~b}$.

LaBarre, E. E.; Ahlstrom, R. H. \& Noble, W. H. Narrow diameter implants for mandibular denture retention. J. Calif. Dent. Assoc., 36(4):283-6, 2008.

Lekholm, U. Immediate/early loading of oral implants in compromised patients. Periodontol. 2000, 33:194-203, 2003.

Maurer, S.; Hayes, C. \& Leone, C. Width of keratinized tissue after gingivoplasty of healed subepithelial connective tissue grafts. J. Periodontol., 71(11):1729-36, 2000.
Misch, C. E.; Wang, H. L.; Misch, C. M.; Sharawy, M.; Lemons, J. \& Judy, K. W. Rationale for the application of immediate load in implant dentistry: part II. Implant Dent., 13(4):31021, 2004.

Mombelli, A.; Van Oosten, M. A.; Schurch, E. Jr. \& Land, N. $P$. The microbiota associated with successful or failing osseointegrated titanium implants. Oral Microbiol. Immunol., 2(4):145-51, 1987.

Morneburg, T. R. \& Pröschel, P. A. Success rates of microimplants in edentulous patients with residual ridge resorption. Int. J. Oral Maxillofac. Implants, 23(2):2706, 2008.

Naert, I.; Gizani, S.; Vuylsteke, M. \& van Steenberghe, D. A 5 -year randomized clinical trial on the influence of splinted and unsplinted oral implants in the mandibular overdenture therapy. Part I: Peri-implant outcome. Clin. Oral Implants Res., 9(3):170-7, 1998.

Nazarian, A. Mini dental implants: immediate gratification for patient and provider. Dent. Today, 24(10):110, 112, 2005.

Preoteasa, E.; Imre, M.; Preoteasa, C. T.; Marin, M. \& Lerner, $\mathrm{H}$. Aspects of oral morphology as decision factors in mini-implant supported overdenture. Rom. J. Morphol. Embryol., 51(2):309-14, 2010.

Raghoebar, G. M.; Schoen, P.; Meijer, H. J.; Stellingsma, K. \& Vissink, A. Early loading of endosseous implants in the augmented maxilla: a 1-year prospective study. Clin. Oral Implants Res., 14(6):697-702, 2003.

Rutar, A.; Lang, N. P.; Buser, D.; Bürgin, W. \& Mombelli, A. Retrospective assessment of clinical and microbiological factors affecting periimplant tissue conditions. Clin. Oral Implants Res., 12(3):189-95, 2001.

Scepanovic, M.; Calvo-Guirado, J. L.; Markovic, A.; Delgardo-Ruiz, R.; Todorovic, A.; Milicic, B. \& Misic, T. A 1-year prospective cohort study on mandibular overdentures retained by mini dental implants. Eur. J. Oral Implantol., 5(4):367-79, 2012.

Sendax, V. I. Mini-implants as adjuncts for transitional prostheses. Dent. Implantol. Update, 7(2):12-5, 1996.

Sennerby, L. \& Meredith, N. Implant stability measurements using resonance frequency analysis: biological and biomechanical aspects and clinical implications. Periodontol. 2000, 47:51-66, 2008.

Shatkin, T. E.; Shatkin, S.; Oppenheimer, B. D. \& Oppenheimer, A. J. Mini dental implants for long-term fixed and removable prosthetics: a retrospective analysis of 2514 implants placed over a five-year period. Compend. Contin. Educ. Dent., 28(2):92-9, 2007. 
Siddiqui, A. A.; Sosovicka, M. \& Goetz, M. Use of mini implants for replacement and immediate loading of $2 \mathrm{sin}$ gle-tooth restorations: a clinical case report. J. Oral Implantol., 32(2):82-6, 2006.

Sohrabi, K.; Mushantat, A.; Esfandiari, S. \& Feine, J. How successful are small-diameter implants? A literature review. Clin. Oral Implants Res., 23(5):515-25, 2012.

Uribe, R.; Peñarrocha, M.; Balaguer, J. \& Fulgueiras, N. Immediate loading in oral implants. Present situation. Med. Oral Patol. Oral Cir. Bucal, 10(Suppl. 2):E143-53, 2005.

Velasco Ortega, E.; Segura Egea, J. J.; Linares Gancedo, D.; Medel Soteras, R. \& Poyato Ferrera, M. La carga inmediata de implantes transicionales en sobredentaduras mandibulares en adultos mayores. Av. Periodoncia Implant. Oral, 16(2):107-13, 2004.

Zahran, A.; Mostafa Zaki, B. \& Medhat, A. Immediate replacement of agenic lateral incisors using one-piece mini and midi dental implants. J. Appl. Sci. Res., 9(1):18496, 2013.
Correspondence to:

Jorge Jofré, DDS, PhD

Director

Center for Advanced Prosthodontics and Implant Dentistry University of Concepcion

Concepción

CHILE

Email: accruxx@gmail.com

Recibido : 15-05-2014

Aceptado: 23-10-2014 